\title{
PROBLEM KEADILAN GENDER DAN HAK-HAK ASASI PEREMPUAN DALAM ISLAM
}

\author{
Oleh: Samsuri * \\ Abstract
}

This article explores the gender and human rights issues in the Islamic community. There are problems originally coming from interpretation of Islamic teachings that be gender biased. According to Riffat Hassan, a feminist of Mustim.world, it is.called as "Islamic patriarchal". In the Shariat (Islamic law) area, it is caused discrimination of gender and religion. There are some factors that rise from (1) cultural construction and the hegemony of interpretation authority of the sacred texts, and (2) the prejudice of cultural and the ambiguity of political interest. In this respect Abdullahi Ahmed An-Na'im offers ideas on deconstruction of Islamic Shariat and Masdar Farid Mas'udi about "the figh of empowerment" could be elaborated as a model of the awareness process for achieving of gender justice and respect of women rights in the Muslim community.

\section{نحكاصن}

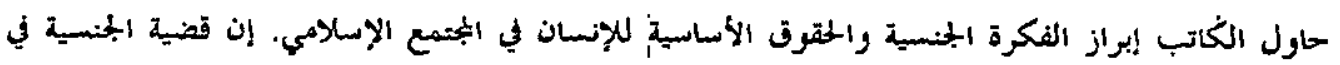

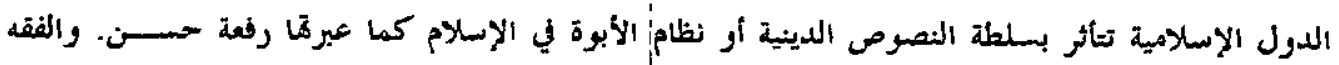

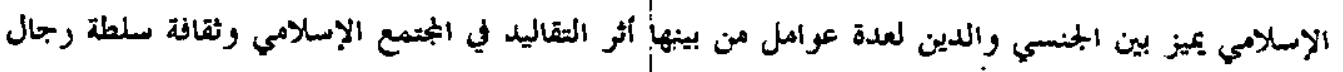

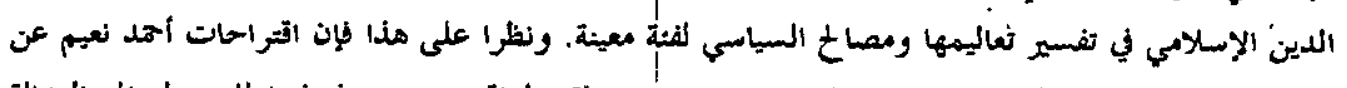

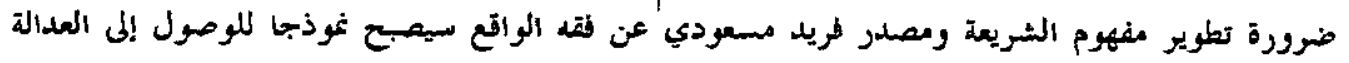

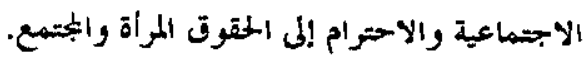

Kata Kunci: Gender, Keadilan, Hak Asasi Manusia

\footnotetext{
- Peserta Program S3 IAIN Sunan Kalijaga dan Dosen Luar Biasa Fakultas Ilmu Sosial Universitas Negeri Yogyakarta
} 


\section{A. Pendahuluan}

Tenggambaran perempuan sebagai makhluk "setengah manusia" (inhu man) oleh tafsiran-tafsiran teologis-patriarkhis dari penganut (pemuka/ ulama) agama-agama "samawi" seperti Yahudi, Kristen dan Islam, berimplikasi kepada ketidakadilan gender dan perampasan hak-hak asasi perempuan sebagai makhluk Tuhan yang diciptakan bermartabat sama di hadapan-Nya sebagai manusia. Di pihak lain, pencitraan laki-laki sebagai "makhluk utama" mendapäkan legitimasinya dari bentuk penafsiran teks-teks agama (tradisi/ kitab suci), sehingga ia berhak memiliki kaum perempuan sebagaimana layaknya memiliki barang.

$\because$ Di dunia Islam, persoalan ketidakadilan gender dan hak-hak asasi perempuan bisa dilihat, sebagai contoh, pada persoalan hak-hak reproduksi perempuan yang sangat jarang diperbincangkan sebagai isu pokok untuk pemberdayaan di kalangan perempuan sendiri. Hal ini lebih disebabkan karena betapa dominannya ('ulama) laki-laki melakukan penafsiran Qur'an dan penjelasan hadis Nabi, yang berkaitan dengan perempuan. Akibatnya, pelbagai isu perempuan dalam Qur'an dan hadis cenderung ditafsirkan secara tidak objektif, sehingga merugikan kaum perempuan. Sebagai contoh adalah penafsiran ayat Qur'an yang berbunyi: "Istrimu adalah ladangmu (untuk ditanami), maka datanglah ke ladang itu sesukamu" (Q.S. 2:223). Ayat ini besár kemungkinan lebih dimaksudkan sebagai pęmberitahuan tentang kesuburan wanita, dari pada tentang seks. Akan tetapi para 'ulama menafsirkannya sebagai diktum bahwa wanita atau istri, dalam keadaan apapun harus memenuhi keinginan seksual suami. ${ }^{1}$

Ada banyak contoh penafsiran serupa yang memunculkan pemahaman yang bias lèlaki. Masdar Farid Mas'udi menyebutkan bias tersebut antara lain terhadap pemikiran bahwa: (1) Perempuan dan lelaki tidak setara, dengan menjustifikasi pada sebuah hadis ahad: "Hawa (perempuan) dicipta dari tulang. rusuk Adam (lelaki)", padahal dalam Qur'an tidak ada ayat yang mengatakan demikian, kecuali tafsir para 'ulama atas ayat 1 Surat An-Nisa; (2) Pada bakat moral dan etikanya, dengan menjustifikasi sebuah hadis bahwa "Wanita sebagai sumber fitnah"; (3) Pada kemampuan fisik maupun mentalnya, dengan, menjustifikasi hadis ahad: "Perempuan mengidap kekurangan baik akal maupun agamanya", kurangnya akal buktinya kesaksiannya hanya dihargai separoh lelaki, kurangnya agama buktinya kalau menstruasi tidak salat. ${ }^{2}$

\footnotetext{
1 Masdar F. Mas'udi, Rosalia Scortino dan Lies Marcoes, 1997, "Learning from Islam: Advocacy of Reproductive Rights in Indonesian Pesantren", Jumnal Studia Islamika, Vol. 4, No. 2, hal. 83-34.

2 Masdar F. Mas"udi, 1997, "Potensi Perubahan Relasi Gender Lingkungan Umat Islam: Sebuah Pengalaman". dalam Seminar Nasional Islam dan Hak-Hak Reproduksi Perempuan di Indonesia oleh P3M Jakarta, 24-26 November, hal. 3-4.
} 
Bias-bias tersebut, menurut Wardah Hafidz ${ }^{3}$, menunjukkan bahwa prinsipprinsip patriarkhi sangat mewarnai karena pada dasarnya penggunaan kekuasaan terhadap orang-orang yang lebih lemah (atau yang dianggap lebih lemah) merupakan inti dari ideologi patriarkhi. Dengan demikian, kecenderungan diskriminatif boleh jadi karena masalah interpretasi atau penafsiran ayat-ayat yang tidak selalu bisa dibaca secara harfiah, naratif ataupun legal saja, dan mendapat warna dari sistem nilai yang berlaku, yakni patriarkhi.

Lebih memprihatinkan lagi, bahwa model penafsiran ini telah menjadi pola umum pandangan masyarakat Muslim, khususnya Muslim Indonesia tentang isu perempuan. Akibatnya, hak-hak mendasar perempuan yang diakui dalam Islam cenderung diabaikan dan tidak digunakan sebagai basis argumen dalam kesimpulan hukum tertentu. Hal ini diperparah oleh kenyataan bahwa pesantren sebagai lembaga pendidikan yang berperan memelihara pemikiran keagamaan termasuk yang mengadopsi pola penafsiran yang merugikan hakhak reproduksi perempuan. Penafsiran Qur'an dan hadits Nabi yang cenderung menempatkan perempuan pada posisi inferior di hadapan laki-laki menjadi 'wacana pemikiran' yang luas berkembang di kalangan pesantren. ${ }^{4}$

Posisi inferior perempuan di hadapan lelaki di kalangan pesantren diperkuat citranya, antara lain dominannya pengaruh kajian seperti Kitab Syarh Uqud al-Lujayn fi Bayan Huquq al-Zawajayn karya Muhammad 'Umar Nawawi al-Bantani. Dalam kitab fiqh ini, Nawawi banyak mengutip hadits berkaitan dengan kehidupan perempuan dalam rumah tangga, seperti hak-hak dan kewajiban suami-istri. ${ }^{5}$ Kendatipun kitab tersebut menyebut-nyebut bahwa suami yang sangat baik adalah menjadi terbaik bagi keluarganya, namun kritik yang bersifat seksisme kepada Nawawi ini terutama kepada pandangan keliru seakan-akan dia menjustifikasi hadits-hadits untuk memberatkan tanggungjawab - khususnya persoalan reproduksi - kepada perempuan (istri). ${ }^{6}$

Secara kodrati perempuan mengemban fungsi reproduksi umat manusia yang utamanya meliputi mengandung, melahirkan, dan menyusui anak. Dalam Qur'an (S. 46:15; 31:14) fungsi kemanusiaan yang sangat berat ini sangat diapresiasi demikian mendalam. Bahkan, Nabi sendiri dalam sebuah hadis yang diriwayatkan Bukhari dan Muslim dari Abu Hurairah mengatakan bahwa orang yang berhak menerima bakti adalah ibu sampai tiga kali, baru kemudian satu kali disebut bapak. Dengan kata lain, melihat penafsiran itu maka manusia

\footnotetext{
${ }^{3}$ Wardah Hafidz, 1995, "Islam dan Gerakan Feminisme", Jurnal Islamika, No. 6, hal. 103.

"Masdar F. Mas'udi, Rosalia Scortino dan Lies Marcoes, op.cir., hal. 84.

"Naqiyah Mukhtar, 1997. "Hak dan Kewajiban Suami Istri dalam Pandangan Kitab Kuning: Studj terhadap Syarh Uqud al-Lujayn fi Bayan Huquq al-Zawajayn Karya Muhammad 'Umar Nawawi al-Banteni", Jurnal Ulumul Qur'an, No. 4, Vol, VII, hal. 26-34.

- Abd. Rachman, 1995, "Nawawi al-Bantani: An Intellectual Master of the Pesantren Tradition", Jurnal Studia Islamika, Vol. 3, No. 3, hal. 104-5.
} 
yang paling terhormat di muka bumi ini peringkat pertama, kedua, dan ketiga adalah ibu, baru urutan keempat adalah bapak. ${ }^{7}$

Persoalan selanjutnya, kalau derajat seorang ibu di mata anak bisa tiga kali lipat dibanding seorang ayah, mengapa di hadapan suami sendiri derajat ibu (istri) terpuruk di bawahnya? Rendahnya derajat seorang ibu (istri) di hadapan ayah (suami) ini bukan saja didukung oleh pandangan budaya tapi juga tafsir agama. Menurut Masdar F. Mas'udi ${ }^{8}$, faktor-faktor inilah yang telah melemahkan hak-hak kaum perempuan. Hak-hak yang seharusnya melekat pada kodrat perempuan selaku pengemban fungsi reproduksi umat manusia.

Dari seluruh uraian di atas, tampak adanya ketidakadilan gender dan "hilangnya" hak-hak asasi perempuan dalam masyarakat Islam. Bagaimanakah keadilan gender dan hak-hak asasi perempuan yang diperjuangkan Islam? Apa sajakah problem implementasi keadilan gender dan hak-hak asasi perempuan di masyarakat Muslim? Berangkat dari pertanyaan-pertanyaan itulah, tulisan ini akan berupaya menguak gagasan keadilan gender dan hakhak asasi perempuan menurut idealitas-normatif Islam, sehingga tampak jelas keadilan dan hak-hak perempuan yang sungguh-sungguh otentik ditekankan Islam, bukan produk budaya-sejarah (kaum laki-laki).

\section{B. Keadilan Gender dan Hak-Hak Asasi Perempuan dalam Islam}

Pokok persoalan ketidakadilan gender dalam masyarakat Muslim, pertamatama dapat ditelusuri dalam istilah Riffat Hassan yang disebutnya sebagai "Islam Patriarkhi".9 "Islam Patriarkhi" merupakan bentukan sejarah dominasi kaum laki-laki dalam menafsirkan sumber-sumber pokok ajaran Islam, yaitu Qur'an dan Hadis Nabi Muhammad. Sumber-sumber tersebut hanya ditafsirkan oleh laki-laki Muslim yang tidak bersedia melaksanakan tugas-tugas pendefinisian status ontologis, teologis, sosiologis dan eskatologis perempuan Muslim.

Isu pokok yang mendasari "Islam Patriarkhi" tampak pada asumsi teologis yang dibangun menurut tafsiran terhadap Qur'an dan Hadits itu sendiri. Asumsi tersebut menyatakan keyakinan bahwa laki-laki lebih unggul dari perempuan, karena: (a) ciptaan Tuhan yang utama adalah laki-laki, bukan perempuan, lantaran diyakini bahwa perempuan tercipta dari tulang rusuk laki-laki, sehingga perempuan adalah makhluk derivatif dan secara ontologis bersifat sekunder;

${ }^{7}$ Masdar F. Mas'udi, 1997, Islam dan Hak-Hak Reproduksi Perempuan: Dialog Fiqih Pemberdayam, Bandung: Mizan, hal. 71-72.

Ibid, hal. 75-78. Kategori Masdar ini sangat bányak memadukan teks Islam dengan isi "Implication of the ICPD Programme of Action" Bab VII, terutama butir 7.2 dan 7.3. Lihat pula Kartono Muhammad, 1998 , Koneradiksi dalam Kesehatan Reproduksi, Jakarta: Pustaka Sinar Harapan, hal. 6.

9Istilah "Islam Patriarkhi" ini dapat dibaca dalam Riffat Hassan, 1995, "Perempuan Islam dan Islam Pasca Patriarkhi", dalam Team LSPPA, ed., Sesara di Hadapan Allah:Relasi Perempuan dan Laki-laki dalam Tradisi Islam Pasca Patriarkhi, penerjemah Team LSPPA, Yogyakarta: LSPPA, hal. 70-75. 
(b) bahwa perempuan, bukan laki-laki, merupakan sebab utama kejatuhan manusia atau terusirnya manusia dari Surga Aden, karenanya semua anak perempuan Hawwa dibenci, dicurigai dan dikutuk; (c) bahwa perempuan diciptakan bukan saja dari laki-laki tapi juga untuk laki-laki. ${ }^{10}$

Asumsi-asumi teologis "Islam Patriarkhi" ini berđampak buruk terhadap persoalan hak-hak asasi perempuan sébagai sesama manusia. Hak-hak asasi manusia (HAM) perempuan di bidang politik, ekonomi, sosial, budaya dan sipil menjadi tereliminasi dalam pandangan teologis "Islam Patriarkhi". Sebagai contoh, di bidang politik perempuan tidak mampu dan berhak menjadi pemimpin, sehingga perempuan selalu di bawah dan perlu kepemimpinan laki-laki di segala aspek. Di bidang| ekonomi, dalam hal waris misalnya, perempuan hanya berhak mewarisi separuh dari laki-laki. Atau pengertian yang lain, laki-laki bergerak di bidang produktif sedangkan perempuan di kawasan reproduktif. Laki-laki di ruang publik, sedangkan perempuan berada di ruang domestik Dalam kesaksian hukum, kesaksian perempuan bernilai hanya setengah kesaksian laki-laki.

Dalam kawasan syariah, mengutip 'Abdullahi Ahmed An-Na'im, ${ }^{11}$ asumsi "Islam Patriarkhi" menimbulkan diskriminasi gender dan agama.'Diskriminasi gender dan agama ini diabsahkan dengan pernyataan bahwa "seorang lakilaki Muslim boleh mengawini perempuan Kristen atau Yahudi, tetapi seorang laki-laki Kristen atau Yahudi tidak boleh mengawini perempuan Muslim." Contoh-contoh diskriminasi berdasarkan gender dalam hukum keluarga dan hukum perdata mencakup hal-hal berikut:

Laki-laki Muslim dapat mengawini hingga empat perempuan dalam waktu bersamaan, tetapi perempuan Muslim hàya dapat kawin dengan seorang laki-laki dalam waktu yang bersamaan (QS. 4:2). |

Seorang laki-laki Muslim dapat menceraikan istrinya, atau seorang dari istri-istrinya dengan meninggalkan begitu saja tanpa akad, talaq, tanpa berkewajiban memberikan berbagai alasan atau pembenaran tindakannya terhadap seseorang perempuan atau suatu otorita. Sebaliknya seorang perempian Muslim dapat bercerai hanya dengan kerelaan suami atau dengan surat keputusan pengadilan yang mengijinkannya dengan dasar-dasar khusus, seperti ketidakmampuan suami dan keengganannya untuk mengurus istri (QS. 2:226-232).

Dalam pewarisan, seorang perempuan Muslim menerima bagian lebih sedikit dari bagian laki-laki Muslim ketika keduanya|berada pada tingkatan yang sama dalam hubungannya dengan seseorang yang meninggal (Q.S. 4:11 dan 4:176). ${ }^{12}$

${ }^{10} \mathrm{Jid}$, , hal. 74.

" Abdullahi Ahmed An-Na'im, 1994, Dekonstruksi Syari 'ah: Wacana Kebebasan Sipil, Hak Asasi Manusia dan Hubungan Internasional dalam Islam, penerjemah Ahmad Suaedy dan Amiruddin Arrani, Yogyakarta: LKiS, hal. 336-346.

12 Ibid., hal. 337-338. 
Untuk mengatasi problem ketidakadilan gender dan tidak diakuinya hakHAM perempuan ini, ada beberapa tawaran menarik yang diajukan baik oleh Riffat Hassan, Abdullahi Ahmed An-Na'im maupun Masdar F. Mas'udi. Riffat Hassan mengajukan anti-tesa "Islam Patriarkhi" dengan "Islam Pasca Patriarkhi" atau "Islam Qur'ani". ${ }^{13}$ "Islam Qur'ani" ini berpendirian bahwa Tuhan yang berbicara melalui Qur'an bercirikan keadilan dan dinyatakan dengan sangat jelas dalam Qur'an bahwa Tuhan tidak akan pernah berbuat $z u l m$ (tidak jujur, tirani, pemerasan dan perbuatan yang salah). Karenanya, Qur'an, sebagai firman Tuhan tidak bisa dijadikan ketidakadilan manusia, dan ketidakadilan yang membuat perempuan Muslim ditundukkan, tidak bisa dianggap berasal dari Tuhan. Secara historis, beberapa ayat di dalam Qur'an telah ditafsirkan sedemikian rupa sehingga nampak mendukung apa yang tampak - dari perspektif feminis Muslim abad ke-20 - sebagai cara-cara berpikir dan bersikap yang tidak adil. Namun dengan kekayaan bahasa Arab yang luar biasa, di mana setiap kata memiliki makna dan nuansa sangat banyak, adalah mungkin - dan perlu - untuk menginterpretasikan kembali ayat-ayat ini secara berbeda sehingga makna dan implikasinya tidak bertentangan dengan keadilan Tuhan. ${ }^{14}$

Sementara itu, untuk keluar dari diskriminasi gender dan agama yang berakibat pula pada ketidakadilan gender dan perampasan hak-hak asasi manusia perempuan dalam Islam, An-Na'im menawarkan satu dekonstruksi syari'ah dengan logika prinsip evolusioner yang diajukan oleh Mahmoud Mohamed Thaha. ${ }^{15}$ Penerapan prinsip interpretasi evolusioner terhadap masalah-masalah diskriminasi khusus terhadap perempuan dan non-Muslim dapat diilustrasikan oleh aturan syari'ah yang melarang perkawinan antara seorang perempuan Muslim dengan laki-laki non-Muslim. Aturan ini didasarkan pada kombinasi operasi perwalian lelaki, dalam kasus ini suami terhadap istrinya, dan orang Muslim terhadap seorang non-Muslim. Karena suami non-Muslim tidak dapat menjadi wali istri-Muslimahnya, maka syari'ah melarang perkawinan tersebut. Jika baik dari perwalian, suami terhadap istrinya maupun orang Muslim terhadap non-Muslim, dihapus, maka tidak akan ada lagi pembenaran terhadap larangan perkawinan antara seorang perempuan Muslim dengan laki-laki non-Muslim. Prinsip evolusioner Mahmoud Thaha ini menolak kedua tipe perwalian tersebut. Prinsip evolusioner juga akan menghapus kemungkinan alasan larangan perkawinan yang lain antara perempuan Muslim dengan laki-laki non-Muslim, yaitu asumsi bahwa seorang istri lebih rentan terhadap pengaruh suaminya daripada sebaliknya. Yakni, seandainya perkawinan itu diijinkan, maka akan lebih mungkin bahwa suami non-Muslim akan mempengaruhi istri Muslimnya keluar dari Islam, daripada

${ }^{13}$ Riffat Hassan, op.cit., hal. 99-100.

:4 Ibid., hal. 99.

${ }^{15}$ Abdullahi Ahmed An-Na'im, op.cit., hal. 344-346. 
istri tersebut akan menyerèt suami ke dalam Islam. Tentu saja, penerapan prinsip evolusioner Mahmoud Taha ini amat bergantung kepada penghapusan seluruh aspek hukum yang diskriminatif terhadap perempuan, yaitu dengan jalan mendorong dan menopang suatu pandangan positif terhadap perempuan.

Pada bagian lain, Masdar F. Mas'udi menawarkan "fiqh pemberdayaan" untuk mengatasi ketidakadilan gender. Beranjak dari eksplanasi Qur'an bahwa kedudukan laki-laki dan perempuan keduanya sama-sama manusia seutuhnya, maka sudah tentu mereka berkedudukan setara. Ini dikuatkan dengan nash bahwa di hadapan Allah, semua manu'sia sama belaka tidak peduli berkelamin laki-laki ataupun perempuan. Yang membedakan satu dari yang lainnya hanyalah tingkat ketakwaannya (QS. 49:13). Di samping itu, dalam QS. 9: 71 tampak jelas prinsip hubungan kemitraan antara laki-laki dan perempuan. Demikian dalam konteks kehidupan' keluarga antara suami-istri ditegaskan bahwa "Istri adalah pakaian/pelindung bagi suami, dan suami adalah pakaian/ pelindung bagi istri" (QS. 2:187). ${ }^{16}$ ।

\section{Problem Kultural dan Politis}

Idealitas keadilan gender dan hak-hak asasi perempuan, seperti telah diusulkan Riffat Hassan, Abdullahi Ahmed An-Na'im maupun Masdar Farid Mas'udi di muka, tampaknya akan selalu terus berbenturan dengan asumsi-asumsi teologis bias gender yang telah mapan di dunia Muslim. Dengan demikian, implementasi konsep keadilan gender dan hak-hak asasi perempuan seperti diidealkan dalam sumber otentik Islam sangat sulit diwujudkan secara uuh.

Sedikitnya ada dua faktor yang dapat dikemukakan di sini yang secara empirik menyebabkan implementasi gagasan keäđilan gender dan hak asasi perempuan tidak mulus diwujudkan. Pertama, faktor konstruk budaya dan hegemoni otoritas penafsiran teks suci agama. Selama berabad-abad sejak wafatnya Nabi Muhammad, penafsiran teks Islam menjadi milik elit dan secara bersamaan adalah berjenis kelamin laki-laki. Terma "Islam Patriarkhi" yang diusung Riffat Hassan di atas tampaknya merupakan refleksi dari adanya hegemoni tafsir tersebut, sehingga, dalam hubungan kemanusiaan kaum perempuan cenderung terpinggirkan dalam pengambilan keputusan terhadap otoritas tafsir keagamaannya sendiri.' 'Yang sangat dominan dirasakan dari bias hegemoni tafsir ini adalah adanya dampak konstruksi kehidupan beragama yang mewujud dalam teks-teks fiqh. S'ebagai contoh, dalam sejarah dinyatakan bahwa Nabi Muhammad menentang sikap fobi di kalangan Yahudi Madinah yang menganggap kotor kaum perempuan yang sedang menjalani masa

${ }^{16}$ Masđar F. Mas'udi, op.cit., hal. 48-49. Sementara kalangan menganggap permbelaan Masdar tentang gender dalam Islam bertolak belakang dengan kenyataan bahwa dia "menemukan jalan yang benar" dengan memilih kembali ke tradisi kyai-kyai pesantren yang' menikahi lebih dari satu istri, sehingga dianggap tidak mendukung gagasan feminis Muslim yang menolak perkawinan poligami. 
menstruasi. Dalam fiqh Islam yang mendasarkan diri kepada hadis-hadis misogini, justru mendukung apa yang dipraktekkan kalangan Yahudi Madinah ketika Nabi Muhammad menentangnya. Dari contoh itu sebenarnya terdapat pelajaran bahwa Islam menekankan bahwa menstruasi - termasuk pula hubungan seksual - memang suatu peristiwa Iuar biasa, tetapi tidak menyebabkan kaum perempuan jatuh martabatnya sebagai manusia. Atau dalam ungkapan Fatima Mernissi, ${ }^{17}$ bahwa peristiwa menstruasi pada kaum perempuan (Muslimah) tidak bisa "memusnahkan" Yang Ilahi serta mengacaukan perintah-perintahNya bagi perempuan. Perumpamaan serupa, ketika perempuan Muslim menghadapi menstruasi di bulan puasa Ramadlan di mana ia tidak dikenai kewajiban berpuasa dan harus menggantikan di bulan lain, bukan berarti bahwa seseorang tersebut menjadi kehilangan haknya untuk mendekatkan diri kepada Tuhan serta mendapatkan kasih sayang-Nya (dalam bahasa fiqh: meraih pahala) di bulan itu.

Dalam arus politik, misalnya, kita dapat menyaksikan di Indonesia bahwa perempuan itu sempat dianggap tidak mampu memimpin suatu bangsa juga turut didukung oleh hegemoni penafsiran teks fiqh klasik. Demi alasan menegakkan syariat Islam, kita menyaksikan bahwa dalam gelanggang politik Indonesia pasca Pemilu 1999 yang lalu, persoalan kepemimpinan nasional ( jabatan presiden) dari seorang perempuan sempat menjadi pertaruhan masa depan nasib bangsa ini. Fenomena Megawati Soekarnoputri, seorang perempuan yang menjadi ketua partai politik (PDIP) pemeroleh suara terbanyak dalam Pemilu 1999, harus menelan kekalahan untuk mencapai posisi puncak sebagai presiden. Justru kekalahannya itu "diperdaya" oleh "saudaranya" sendiri yang menyatakan bersedia menjadi calon presiden kelompok Poros Tengah, 18 yaitu Abdurrahman Wahid. ${ }^{19}$ Asumsi konstruksi fiqh yang menganggap lemah seorang Megawati sebagai seorang perempuan untuk memimpin suatu negara ini diperkuat sebelumnya oleh keputusan Kongres Umat Islam bulan September 1999 di Jakarta. ${ }^{20}$ Dari sini tampak bahwa ada

${ }^{17}$ Fatima Mernissi, 1991, Wanita di dalam Islan, penerjemah Yaziar Radianti, Bandung: Pustaka, hal. xxi.

${ }_{18}$ Poros Tengah merupakan aliansi partai-partai Islam dan berbasis konstituen masyarakat Islam di bawah pimpinan Amien Rais (Ketua Umum Partai Amanat Nasional, dan bekas Ketua PP Muhammadiyah) berhasi] mengharu biru peta politik nasional, terutama keberhasilan kelompoknya untuk memastikan siapa presiden pasca pemilu 1999. Peristiwa serupa, di bawah dukungan TNI/Polri, Poros Tengah berhasil menjatuhkan Abdurrahman Wahid dari jabatan Psesiden pada 23 Juli 2001, setelah Presiden Abdurrahman Wahid mengeluarkan Dekrit Presiden yang antara lain membekukan lenbaga MPR/DPR.

${ }^{19}$ Megawati dan Abdurrahman Wahid - biasa dipanggil Gus Dur - dianggap mewakili komunitas nasionalis dan Islam. Pada paruh pertama 1990-an, baik Megawati maupun Abdurrahman Wahtd sama-sama menjadi simbol oposisi yang mewakili massa arus bawah korban rezim politik Orde Baru.

Selain faktor gender, penolakan terhadap Megawati sebagai calon presiden pada pra Sidang Umum MPR 1999, adalah karena faktor agama. Megawati dinilai tidak jelas identitas keberagamaannya saat ia turut hadir dalam acara peribadatan di salah satu pura di Bali. Peristiwa ini dimanfaatkan oleh Ahmad Muflih Saefuddin, fungsionaris Dewan Pimptnan Pusat Partai Persatuan Pembangunan (DPP PPP) dan anggota Kabinet Habibie, untuk mempersoalkan identitas keagamaan Megawati yang tidak jelas apakah Hindu atau Muslim. Penyoalan A.M. Saefuddin ini menimbulkan reaksi keras masyarakat Hindu-Bali, dan sempat menimbulkan ketegangan politik nasional. 
masalah yang mengganggu sebagian kaum lelaki Muslim modern, bukan karena Qur'an ataupun Sunnah Nabi maupun tradisi Islam, tetapi sematamata karena hak-hak yang sama bagi kaum perempuan untuk memimpin dalam hal ini Megawati menjadi presiden pada Sidang Umum MPR Oktober 1999 - dianggap bertentangan dengan kepentingan kaum elit lelaki.

Kedua, prasangka budaya dan ambiguitas politik. Di kalangan masyarakat Muslim pada umumnya, ada prasangka yang menjadi keyakinan bahwa persoalan keadilan gender dan hak-hak asasi (manusia) perempuan sering disalah mengerti sebagai suatu produk berpikir (kebudayaan) Barat, yaitu feminisme, sehingga selain dianggap tidak universal juga tidak "Islami". Padahal, keadilan dan martabat kemanusiaan itu sendiri adalah universal, tidak mengenal perbedaan ras, gender, golongan dan wilayah, sehingga upaya melindungi dan menegakkan keadilan serta hak-hak tersebut adalah suatu kebajikan yang bersifat universal pula.

Ambiguitas politik nampak sekali dari kenyataan bahwa dalam pergaulan internasional negara-negara mayoritas berpenduduk Muslim ex-officio terikat dengan rejim hukum internasional di bawah payung Perserikatan BangsaBangsa (PBB) lantaran keanggotaannya di PBB. Persoalan gender dan HAM sebagaimana bisa disimak dalam sejumlah dokumen PBB seperti Universal Declaration of Human Rights (1948) dan Convention on Elimination of All Discrimination Against Women (CEDAW, 1979), merupakan salah satu contoh betapa negara-negara Islam bersikap ambivalen terhadap dokumen hukum internasional itu. Meskipun sebagian besar negara-negara Islam sudah meratifikasi dokumen-dokumen itu, sehingga ada dorongan supaya menegakkan isi dokumen-dokumen hukum internasional itu sebagai bentuk kesungguhan menjadi anggota PBB, namun di sisi lain berseberangan dengan yurisdiksi nasional mereka sendiri karena peran syariat Islam dalam sistem hukum domestik negara-negara tersebut. ${ }^{21} \mathrm{Di}$ sini terdapat konflik kepentingan politik nasional dan internasional.

Yang mengkhawatirkan adalah 'bahwa konflik ini diperluas dengan penggambaran sebagai konflik antara Islam (dalam bentuk fiqh) dengan Barat (dokumen PBB). Padahal sejatinya Islam sendiri tidak mengenal Barat atau Timur ketika berbicara keadilan dan martabat kemanusiaan. Prinsip Islam yang bersentral pada tauhid mengajak umatnya untuk melihat bahwa Tuhan Yang Esa itu transenden dan di luar soal-soal gender. ${ }^{22}$ Dari prinsip itu kita bisa menemukan universalitas kesetaraan gender sesama manusia di hadapan manusia. Dengan begitu, HAM sama universalnya dengan elan vital

\footnotetext{
" Contoh ambiguitas di negara-negara Isłam ini dapat disimak dalam Abdullahi Ahmed An-Na'im, op.cit., hal. $340-343$

"Maura O'Neill, 1990, Women Speaking, Women Listening: Women in Interreligious Dialogue, Maryknoll, New York: Orbis Books, hal. $3 i$.
} 
feminisme ${ }^{23}$ yang mengedepankan keadilan relasi antara laki-laki dan perempuan, tanpa diskriminasi ras, bahasa, dan agamanya.

\section{Penutup}

Dengan menyadari kesulitan implementasi idealitas keadilan gender dan HAM perempuan sebagaimana disebutkan di muka, jalan keluar yang dapat dilakukan adalah dengan melakukan proses penyadaran (conscientization) terhadap kaum Muslim baik laki-laki maupun perempuan bahwa ada ketidakadilan dan pelanggaran HAM berbasis gender. Upaya LSM-LSM seperti P3M Jakarta dengan komunitas pesantrennya atau LBH APIK Jakarta dan Rifka Annisa Yogyakarta, yang berjuang membela keadilan gender dan hak-hak asasi perempuan sebagai umat Tuhan, sebenarnya menjadi langkah penting untuk mewujudkan cita-cita Islam mengenai problem gender dan HAM itu sendiri, kendatipun tidak harus berlabel LSM-agama.

Hanya saja, pada taraf yang luas, problem gender dan HAM ini perlu melibatkan elemen masyarakat lain tanpa adanya diskriminasi SARA. Hal ini perlu menjadi sebuah kesadaran bersama bahwa persoalan gender dan HAM itu sendiri tidak melulu dihadapi masyarakat Muslim, tetapi juga menjadi persoalan yang harus dipecahkan bersama-sama umat manusia lainnya.

\section{DAFTAR PUSTAKA}

Hafidz, Wardah, 1995, "Islam dan Gerakan Feminisme," Jurnal Islamika, No. 6

Hassan, Riffat, 1995, "Perempuan Islam dan Islam Pasca Patriarkhi", dalam Team LSPPA, ed., Setara di Hadapan Allah: Relasi Perempuan dan Laki-laki dalam Tradisi Islam Pasca Patriarkhi, penerjemah Team LSPPA, Yogyakarta: LSPPA.

Mas'udi, Masdar F., 1997, "Potensi Perubahan Relasi Gender Lingkungan Umat Islam: Sebuah Pengalaman", dalam Seminar Nasional Islam dan Hak-Hak Reproduksi Perempuan di Indonesia oleh P3M Jakarta, 24-26 November

----, 1997, Islam dan Hak-Hak Reproduksi Perempuan: Dialog Fiqih Pemberdayaan, Bandung:

${ }^{3}$ Ibid, hal. 55 . 
Mas'udi, Masdar F., Rosalia Scortino dan Lies Marcoes, 1997, "Learning from Islam: Advocacy of Reproductive Rights in Indonesian Pesantren", Jurnal Studia'Islamika, Vol. 4, No. 2

Mernissi, Fatima ,1991, Wanita di dalam Islam, penerjemah Yaziar Radianti, Bandung: Pustaka

Muhammad, Kartono, 1998, Kontradiksi dalam Kesehatan Reproduksi, Jakarta: Pustaka Sinar Harapan.

Mukhtar, Naqiyah, 1997, "Hak dan|Kewajiban Suami Istri dalam Pandangan Kitab Kuning: Studi terhadap Syarh Uqud al-Lujayn fi Bayan Huquq aI-Zawajayn Karya Muhammad 'Umar Nawawi al-Banteni", Jurnal Ulumul Qur'an, No. 4, Vol, VII

Na'im, Abdullahi Ahmed An-, 1994, Dekonstruksi Syari'ah: Wacana Kebebasan Sipil, Hak Asasi Manusia dan Hubungan Internasional dalam Islam; penerjemah Ahmad Suaedy dan Amiruddin Arrani, Yogyakarta: LKiS.

O'Neill, Maura, 1990, Women Speaking, Women Listening: Women in Interreligious Dialogue, Maryknoll, New York: Orbis Books

Rachman, Abd., 1995, "Nawawi al-Bantani: An Intellectual Master of the Pesantren Tradition", Jurnal Studia Islamika, Vol. 3, No. 3 